\title{
AN EMPIRICAL STUDY ON LENDING PATTERN AND PERCEPTION OF COMMERCIAL BANKS TOWARDS SMALL AND MEDIUM ENTERPRISES LENDING
}

\author{
Nandini M \\ PhD Research Scholar \\ Department of Management Studies and Research Centre \\ BMS College of Engineering \\ Bull Temple Road, Basavanagudi, Bengaluru, Karnataka 560019, India \\ E-mail: nandinireddym@gmail.com \\ Dr. Shubha B N \\ Professor \& Head of the Department \\ Department of Management Studies and Research Centre \\ BMS College of Engineering \\ Bull Temple Road, Basavanagudi, Bengaluru, Karnataka 560019, India \\ E-mail: bns.mba@bmsce.ac.in
}

Received: August 29, $2021 \quad$ Accepted: September 26, $2021 \quad$ Online Published: October 26, 2021

DOI: $10.46281 /$ ijafr.v8i1.1403

URL: https://doi.org/10.46281/ijafr.v8i1.1403

\begin{abstract}
Micro, Small and Medium sector (MSME) is the most dynamic sector due to its capacity for innovation, competence for advancements and perseverance to face multiple challenges. Though this sector contributes 8 per cent to GDP, 45 per cent towards manufacturing output and 40 per cent of exports. Still, they lack support to grow exponentially. Understanding the lending pattern of the banks and the perception of commercial banks towards MSME lending is essential not only for academic knowledge but also could necessitate policy changes. The objective of the research is to understand the lending pattern of banks to SMEs and the perception of commercial banks towards SME lending. The researcher used both primary and secondary data. Statistical tools ANOVA and Kruskal Wallis tests are used to analyze the collected data. The results indicate that there is no significant difference in the lending pattern of public sector banks, Private sector banks and foreign banks and the bank staff have a similar level of perception on difficulties in lending to SMEs, perception on the rejection of loan, perception on reluctance to serve SME sector, perception on loan default and factors affecting credit decisions irrespective of the type of the bank and experience in SME lending.
\end{abstract}

Keywords: Micro, Small and Medium Enterprises, Commercial Banks, Bank Advances, Lending Pattern, Economic Development.

JEL Classification Codes: G21, G23, G28.

\section{INTRODUCTION}

Small and medium-sized businesses and a sound banking system is the foundation for a strong nation. SMEs occupy a vital place in economic development by offering vast job possibilities at relatively less 
capital costs than big sectors. It enables rural industrialization and thereby decreasing regional imbalances and ensures a fair distribution of national income \& wealth. The World Bank has noted that industrial growth was caused by big companies previously, but SMEs were considered the last main agents for industrialization from the early 1970s onwards.

SMEs are the dominant type of corporate enterprise worldwide. Of the total undertakings, 99\% are small in the EU and approximately $80 \%$ in the U.S. The proportion in India is up to 97\%. SMEs account for more than $98 \%$ and $99.9 \%$ of business in Hong Kong and Korea respectively. In Malaysia and Singapore, they account for $99 \%$ of the small industries. The Indian Economy is expected to grow by more than $8 \%$ per annum till 2021 and becomes the second largest in the world by 2050, The target would be difficult to achieve without the involvement of this sector. The less capital intensive and high labour absorption nature of SMEs made a significant contribution to employment and also to rural industrialization.

For sustainable economic growth micro, small and medium enterprises are essential because they are the major contributors to GDP. In high revenue nations and low revenue nations, this industry makes an average contribution of $49 \%$ to the GDP. The 2010 study from the World Bank disclosed that SMEs are regarded as a growth engine in all countries. The power of the industry lies in the extensive distribution in rural, semi-urban and urban regions which foster entrepreneurship, shorter gestation and a fair share of revenue and wealth. MSME enterprises worldwide, including India, are the vehicles of sustainable and integrated development.

But the major constraint to the growth of SMEs is financing. Smaller entities often do not have the credentials to avail funding from banks or other formal lenders. They often have to go through cumbersome processes and pay exorbitant fees - impacting their competitiveness and growth prospects. Bank takes a longer duration to approve SME loans. In Spain, an SME may end up paying a bank 10\% for a loan at a time when the bank's own cost of funds is close to zero. Lending to SMEs is perceived to be riskier than to large established firms (Hall \& Fang, 2004).

In this backdrop, the research paper aims at understanding the lending pattern and perception of commercial banks towards SMEs.

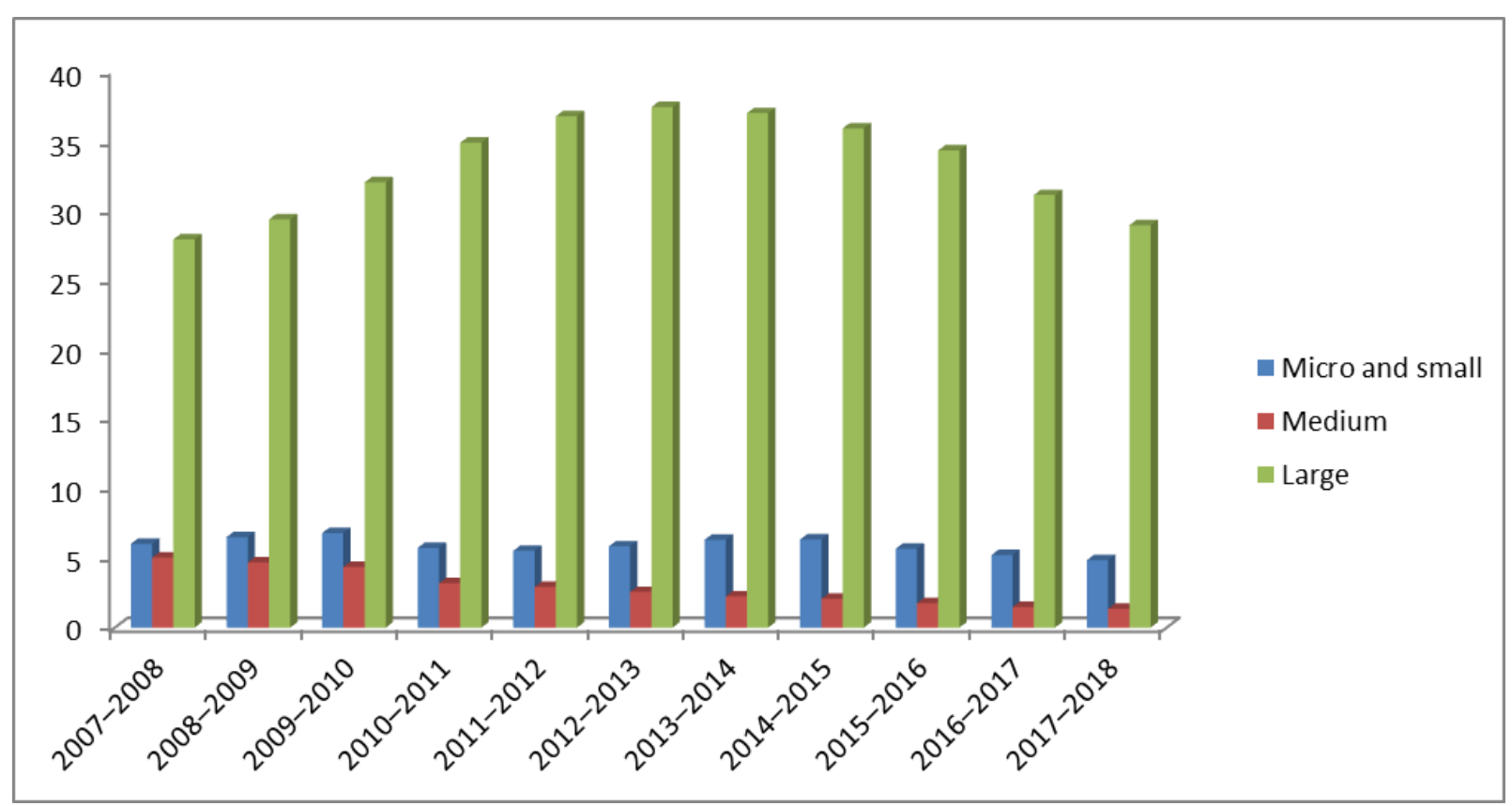

Figure 1. Average growth rate of Micro \& small, medium and large enterprises in percentage 


\section{REVIEW OF LITERATURE}

Fasola et al. (2020) the authors examined the gap by assessing the effect of business credit availability (information asymmetry, bank density, and credit rationing) on the profitability of SMEs in Southwest, Nigeria. The cross-sectional survey design is used in the research. The design is suitable for this study because the study sought information from the respondent's relating to their attitudes, beliefs, feelings, and behaviours. The research concludes bank density, information asymmetry, and credit rationing are seen to be major constraints to the profitability of SMEs.

Choudhury and Goswami (2017) examined the issues associated with institutional lending to MSMEs, extensive literature reviews were done for the period from 2005 to 2016 . The study reveals the factors influencing MSME lending that includes competition among the banks, legal framework by government, Credit policies, lack of information about SME borrowers, firm characteristics and firm size.

Nair and Das (2019) prime minister Mudra Yojna (PMMY) enhanced refinance to SME finance by the banks. Public sector banks are participating in large in PMMY.

Soumya and Jayaprada (2018) the author outlines the importance and need of MSMEs, importance of government support, success and failure of private collaborations and the MSME environment in India with a special focus on the manufacturing sector. An attempt is made to understand the varying perceptions of the policymakers, implementers and beneficiaries (MSMEs) creating the finance gap.

Gupta et al. (2018) study focuses on analyzing the contribution of commercial banks and assessing the factors affecting bankers risk perception towards financing MSMEs in the state of Himachal Pradesh. The study finds that there exists a significant difference in the lending patterns of banks to MSMEs and Public sector banks contribute more towards MSME financing. The banks consider MSME financing as costly and time-consuming still they consider the MSMEs sector comparatively reliable, viable and safe in terms of NPA resulted in increased proportionate lending to this sector.

Jeyaraj and Prakash (2017) explored and reviewed the attitude of the borrowers regarding the lending services of BDFCL. Analysis of the data collected from the borrowers reveals that the majority of the borrowers have a moderate level of satisfaction with the services provided by banks.

Wangmo (2017) the author examines the variables used by the banks to determine the outcome of loan applications of SMEs in Bhutan. The major problem faced by SMEs in Bhutan is Inaccessibility to finance. An In-depth interview of Credit officials to understand the lending behaviour of banks towards SMEs is done. The age and educational qualification of borrowers have a positive relationship while the gender of the owner did not have any effect on bank loan accessibility.

Ghatule and Dubey (2016) the researcher has attempted to throw light on the role of SMEs in the Indian context, challenges \& opportunities ahead for this sector. From the study, the author finds that the absence of adequate credit from formal sources, limited capital Knowledge, lower capacity of production, lack of marketing strategy, Identification of new markets, the challenge of getting skilled manpower are the challenges faced by the SMEs. Awareness should be crated about various incentives, subsidies and schemes to upkeep and boost this Sector.

Shikumo and Mwangi (2016) examined the determinants of lending to SMEs by commercial banks in Kenya. 43 commercial banks were taken as a sample size in the study. From the study, it was inferred that bank size and liquidity are the factors that significantly influence lending to SMEs by commercial banks. Credit risk and interest rate have no significant influence on lending to SMEs by commercial banks in Kenya. Effective policies should be developed to ensure commercial banks grow.

Abdulsaleh and Worthington (2016) the authors investigate the criteria used by loan officers at Bank Al Tanmeya when assessing SMEs loan applications and identify the key reasons leading to SMEs loan applications being denied. Semi-structured interviews were conducted to collect the data. From the study, it was found that the ability to provide collateral, good business plan, applicant's credit history, business experience and type of the business are the major factors considered by the bankers while 
assessing the loan application. Most of the SME loan applications are rejected due to a lack of adequate collateral and a weak business plan.

Chaudhary and Ahalawat (2014) the researcher examined the problems faced by SMEs relating to credit. The objective is to understand the importance, financing of SMEs, hurdles in the SME sector, and to analyze whether the present credit flow system is satisfactory. Data is collected from the bank officers as well as from SMEs. Findings of the study infer that the process of credit flow is well carried out and it is based on proper analysis of borrowers by preparing a proposal for every borrower. Borrowers are satisfied with bank finance.

Irwin and Scott (2010) explored the barriers in raising finance by SMEs in the U.K, particularly the influence of personal characteristics of an entrepreneur. Stratified random sampling is used to select the sample size. Using a telephone survey, data was collected from 400 SMEs. The analysis of the data infers that among the personal characteristics, education made the difference to the source of finance.

\section{RESEARCH METHODOLOGY}

The type of research used in the research is descriptive. The study employs primary and secondary data, Non-probabilistic judgmental sampling is used to collect the primary data from 60 commercial banks of the Bangalore region. To understand the lending pattern, the study period of 15 years from 2005 to 2019 is considered. Secondary data is gathered from annual reports of MSME, RBI, national and international journals, collected data is analysed using SPSS (Statistical Package for Social Sciences) through different statistical tools ANOVA, Kruskal Wallis Test. Conclusion is drawn based on the analysis.

\section{OBJECTIVES OF THE STUDY}

- To understand the lending pattern of banks to SMEs.

- To understand the perception of commercial banks towards SME lending.

\section{HYPOTHESIS OF THE STUDY}

- H0: There is no significant difference in the lending pattern of public sector banks, private sector banks and foreign banks to the SME sector

- H1: There is a significant difference in the lending pattern of public sector banks, private sector banks and foreign banks to the SME sector.

- H0: Perception of commercial banks towards SME lending is the same.

- H2: Perception of commercial banks towards SME lending is not the same.

\section{Lending Pattern of Commercial Banks to SME SECTOR \\ RESULTS AND DISCUSSIONS}

Table 1. Advances of Commercial banks to SMEs from 2005 to 2019

\begin{tabular}{|l|l|l|l|l|}
\hline Sl. No & Year & $\begin{array}{l}\text { Public sector banks (INR } \\
\text { crore) }\end{array}$ & $\begin{array}{l}\text { Private sector banks } \\
\text { (INR crore) }\end{array}$ & $\begin{array}{l}\text { Foreign banks } \\
\text { (INR crore) }\end{array}$ \\
\hline 1 & 2005 & 67,800 & 8,592 & 6,907 \\
\hline 2 & 2006 & 82,434 & 10,421 & 8,430 \\
\hline 3 & 2007 & $1,02,550$ & 13,136 & 11,637 \\
\hline 4 & 2008 & $1,51,137$ & 46,912 & 15,489 \\
\hline 5 & 2009 & $1,91,408$ & 46,656 & 18,063 \\
\hline 6 & 2010 & $2,78,398$ & 64,534 & 21,069 \\
\hline 7 & 2011 & $3,76,625$ & 87,857 & 21,461 \\
\hline 8 & 2012 & $3,96,343$ & $1,10,514$ & 21,760 \\
\hline 9 & 2013 & $5,02,459$ & $1,54,732$ & 30,020 \\
\hline 10 & 2014 & $6,15,976$ & $2,00,138$ & 30,020 \\
\hline
\end{tabular}




\begin{tabular}{|l|l|l|l|l|}
\hline 11 & 2015 & $8,52,689$ & $2,81,548$ & 36,787 \\
\hline 12 & 2016 & $8,20,548$ & $3,59,085$ & 36,374 \\
\hline 13 & 2017 & $8,28,933$ & $4,30,963$ & 36,503 \\
\hline 14 & 2018 & $8,64,598$ & $4,10,760$ & 48,881 \\
\hline 15 & 2019 & $8,80,033$ & $5,63,678$ & 66,939 \\
\hline Total & & $\mathbf{7 0 , 1 1 , 9 3 1}$ & $\mathbf{2 7 , 8 9 , 5 2 7}$ & $\mathbf{4 , 1 0 , 3 4 1}$ \\
\hline
\end{tabular}

Source: Report on 24th Standing Advisory Committee on MSME, FIDD, RBI, September 17, 2019

Table 2. ANOVA Table

\begin{tabular}{|l|l|l|l|}
\hline Source of Variation & Sum of squares & V & Mean Squares \\
\hline Between samples ( Column Means ) & $\mathrm{SSC}=9,93,13,310$ & d.o.f $=\mathrm{c}-1=2$ & $4,96,56,655$ \\
\hline Within Samples (Errors) & $\mathrm{SSE}=18,61,97,793$ & $\begin{array}{l}\text { d.o.f }=\mathrm{c}(\mathrm{r}-1) \\
3(15-1)=42\end{array}$ & $44,33,280$ \\
\hline
\end{tabular}

Source: Computed value from secondary data

The calculated value of $F$ is 11.20 , this is greater than the tabled value $F 0.05=3.22 \alpha=0.05$. This necessitates the rejection of the null hypothesis hence, there is a significant difference in the lending pattern of the public sector, private sector and foreign banks to the SME sector in India.

To understand the perception of bankers towards SME lending, Variables like perception of the bank staff on difficulties in lending to SMEs, perception on the rejection of loans, perception on reluctance to serve SME sector, perception on loan default and factors affecting credit decisions are used. Kruskal Wallis test is employed to understand the banker's perception towards SME lending.

\section{Analysis of Demographic and Lending Characteristics of Bankers}

Table 3. Demographic and Lending characteristics of Bankers

\begin{tabular}{|c|c|c|c|}
\hline Particulars & Items & Number & Percentage \\
\hline \multirow[t]{3}{*}{ Type of the bank } & Public & 34 & 57 \\
\hline & Private & 21 & 35 \\
\hline & Foreign & 05 & 08 \\
\hline \multirow[t]{4}{*}{ Experience in SME Lending } & Less than 1 year & 08 & 13 \\
\hline & More than 1 year less than 3 years & 18 & 30 \\
\hline & More than 3 years less than 5 years & 24 & 40 \\
\hline & More than 5 years & 10 & 17 \\
\hline \multirow[t]{2}{*}{ Training provided } & Yes & 47 & 78 \\
\hline & No & 13 & 22 \\
\hline \multirow[t]{3}{*}{ Separate Department } & MSME separately & 18 & 30 \\
\hline & $\begin{array}{l}\text { Micro and small combined \& } \\
\text { medium enterprises separately }\end{array}$ & 14 & 23 \\
\hline & $\begin{array}{l}\text { SME combined but separately for } \\
\text { large firms }\end{array}$ & 28 & 47 \\
\hline \multirow{3}{*}{$\begin{array}{l}\text { Reasons for delay in } \\
\text { processing the loan }\end{array}$} & Staff shortage & 12 & 20 \\
\hline & Improper documentation & 34 & 57 \\
\hline & $\begin{array}{l}\text { Inadequate information on loan } \\
\text { products }\end{array}$ & 14 & 23 \\
\hline \multirow{2}{*}{$\begin{array}{l}\text { Specialised SME Recovery } \\
\text { units }\end{array}$} & No & 19 & 32 \\
\hline & Yes & 41 & 68 \\
\hline
\end{tabular}




\begin{tabular}{|l|l|c|c|}
\hline Monitoring of loan recovery & No & 36 & 60 \\
\cline { 2 - 4 } & Yes & 24 & 40 \\
\hline \multirow{4}{*}{$\begin{array}{l}\text { Communication of Bank } \\
\text { schemes }\end{array}$} & Wall Posters/Brochures/Signboard & 22 & 37 \\
\cline { 2 - 4 } & TV/Newspaper & 11 & 18 \\
\cline { 2 - 4 } & Personal interaction & 24 & 40 \\
\cline { 2 - 4 } & Internet & 03 & 05 \\
\hline \multirow{4}{*}{ Designing of the product } & Head Office & 13 & 21 \\
\cline { 2 - 4 } & Brach Office & 31 & 52 \\
\cline { 2 - 4 } & Need of the client & 10 & 17 \\
\cline { 2 - 4 } & Standard & 06 & 10 \\
\cline { 2 - 4 } & As per demand & 00 & 00 \\
\hline
\end{tabular}

Source: Primary data

Table 4. Variances and Types of bank

\begin{tabular}{|c|c|c|c|c|}
\hline Variables & $\mathbf{H}_{\mathbf{0}}$ & Statistical Test & P-value & Result \\
\hline $\begin{array}{l}\text { Type of bank and } \\
\text { Difficulties in } \\
\text { lending to SME }\end{array}$ & $\begin{array}{l}\text { The distribution of } \\
\text { difficulties in lending is the } \\
\text { same across the categories } \\
\text { of Type of bank }\end{array}$ & $\begin{array}{l}\text { Kruskal Wallis } \\
\text { Test }\end{array}$ & 0.400 & $\mathrm{H}_{0}$ is accepted \\
\hline $\begin{array}{l}\text { Type of bank and } \\
\text { rejection of loan }\end{array}$ & $\begin{array}{l}\text { The distribution of rejection } \\
\text { of loan is the same across } \\
\text { the categories of Type of } \\
\text { bank }\end{array}$ & $\begin{array}{l}\text { Kruskal Wallis } \\
\text { Test }\end{array}$ & 0.775 & $\mathrm{H}_{0}$ is accepted \\
\hline $\begin{array}{l}\text { Type of bank and } \\
\text { reluctance to serve } \\
\text { SME sector }\end{array}$ & $\begin{array}{l}\text { The distribution of } \\
\text { reluctance to serve SME } \\
\text { sector is the same across the } \\
\text { categories of Type of bank }\end{array}$ & $\begin{array}{l}\text { Kruskal Wallis } \\
\text { Test }\end{array}$ & 0.851 & $\mathrm{H}_{0}$ is accepted \\
\hline $\begin{array}{l}\text { Type of bank and } \\
\text { loan default }\end{array}$ & $\begin{array}{l}\text { The distribution of loan } \\
\text { default is the same across } \\
\text { the categories of Type of } \\
\text { bank }\end{array}$ & $\begin{array}{l}\text { Kruskal Wallis } \\
\text { Test }\end{array}$ & 0.731 & $\mathrm{H}_{0}$ is accepted \\
\hline $\begin{array}{l}\text { Type of bank and } \\
\text { factors affecting } \\
\text { credit decision }\end{array}$ & $\begin{array}{l}\text { The distribution of factors } \\
\text { affecting credit decision is } \\
\text { the same across the } \\
\text { categories of Type of bank }\end{array}$ & $\begin{array}{l}\text { Kruskal Wallis } \\
\text { Test }\end{array}$ & 0.500 & $\mathrm{H}_{0}$ is accepted \\
\hline
\end{tabular}

Source: Primary data

Table 4 reveals the perception of the bank staff on difficulties in lending to SMEs, perception on the rejection of loan, perception on reluctance to serve SME sector, perception on loan default and factors affecting credit decisions do not significantly differ based on the type of bank of the sample respondents. Therefore, it can be said that the bank staff have a similar level of perception on difficulties in lending to SMEs, perception on the rejection of loan, perception on reluctance to serve SME sector, perception on loan default and factors affecting credit decisions irrespective of the type of the bank.

Table 5. Variances and Experience in SME lending

\begin{tabular}{|c|l|l|c|c|}
\hline Variables & \multicolumn{1}{|c|}{ Ho $_{0}$} & Statistical Test & P-value & Result \\
\hline $\begin{array}{l}\text { Experience in SME } \\
\text { lending and }\end{array}$ & $\begin{array}{l}\text { The distribution of } \\
\text { difficulties in lending is the }\end{array}$ & $\begin{array}{l}\text { Kruskal Wallis } \\
\text { Test }\end{array}$ & 0.241 & $\mathrm{H}_{0}$ is accepted \\
\hline
\end{tabular}




\begin{tabular}{|l|l|l|l|l|}
\hline $\begin{array}{l}\text { Difficulties in } \\
\text { lending to SME }\end{array}$ & $\begin{array}{l}\text { same across the categories } \\
\text { of Experience in SME } \\
\text { lending }\end{array}$ & & \\
\hline $\begin{array}{l}\text { Experience in SME } \\
\text { lending and rejection } \\
\text { of loan }\end{array}$ & $\begin{array}{l}\text { The distribution of } \\
\text { rejection of loan is the same } \\
\text { across the categories of } \\
\text { Experience in SME lending }\end{array}$ & $\begin{array}{l}\text { Kruskal Wallis } \\
\text { Test }\end{array}$ & 0.555 & $\mathrm{H}_{0}$ is accepted \\
\hline $\begin{array}{l}\text { Experience in SME } \\
\text { lending and } \\
\text { reluctance to serve } \\
\text { SME sector }\end{array}$ & $\begin{array}{l}\text { The distribution of } \\
\text { reluctance to serve SME } \\
\text { sectoris the same across the } \\
\text { categories of Experience in } \\
\text { SME lending }\end{array}$ & $\begin{array}{l}\text { Truskal Wallis } \\
\text { Test }\end{array}$ & 0.043 & $\mathrm{H}_{0}$ is rejected \\
\hline $\begin{array}{l}\text { Experience in SME } \\
\text { lending and loan } \\
\text { default }\end{array}$ & $\begin{array}{l}\text { The distribution of loan } \\
\text { default is the same across } \\
\text { the categories of } \\
\text { Experience in SME lending }\end{array}$ & $\begin{array}{l}\text { Kruskal Wallis } \\
\text { Test }\end{array}$ & 0.021 & $\mathrm{H}_{0}$ is rejected \\
\hline $\begin{array}{l}\text { Experience in SME } \\
\text { lending and factors } \\
\text { affecting } \\
\text { decision credit }\end{array}$ & $\begin{array}{l}\text { The distribution of factors } \\
\text { affecting credit decision is } \\
\text { the same across the } \\
\text { categories of Experience in } \\
\text { SME lending }\end{array}$ & Test & & \\
\hline
\end{tabular}

Source: Primary data

Table 5 reveals that perception of the bank staff on difficulties in lending to SMEs, perception on the rejection of loan, and factors affecting credit decisions do not significantly differ based on the experience of the sample respondents in SME lending. However, the perception on reluctance to the serve SME sector and perception on loan default significantly differ based on experience in SME lending. Therefore, it can be concluded that the bank staff have a similar level of perception on difficulties in lending to SMEs, perceptions on the rejection of loans, and factors affecting credit decisions irrespective of experience in SME lending. But the sample bankers significantly differ on perception towards reluctance to serve the SME sector and perceptions on loan default based on experience in SME lending.

\section{SUMMARY OF FINDINGS}

From the analysis, it is found that there is a significant difference in the lending pattern of public sector banks, private sector banks and foreign banks. To analyze the perception of the bankers towards SMEs different non-parametric tests are used. The results show that the difficulties in lending to SME, rejection of loan, reluctance to serve SME sector, loan default and factors affecting credit decision is the same across the categories of types of bank, the study also finds that perceptions of the bank staff on difficulties in lending to SMEs, perceptions on the rejection of loan, and factors affecting credit decisions do not significantly differ based on the experience of the bankers in SME lending. Perception of the bankers towards reluctance to serve SME sector and loan default differs across the categories of experience in SME lending.

\section{SUGGESTIONS}

From the analysis, the researcher would like to suggest the following

\section{To SMEs}

- SMEs should provide all material information to the banks so that they can process the loan application of SMEs without any delay. 
- SMEs should be aware of the criteria that banks consider as important in making a lending decision.

- SMEs should explore financing options available with banks and external agencies to maintain liquidity and meet short term requirements.

- Owners/managers of SMEs should undergo training in the areas of maintaining accounts that would not only promote their demand for credit but also increase their access to credit.

\section{To Banks}

- Banks should streamline the lending processes, limit paperwork and be quick to respond to loan applications.

- There should be transparency in loan sanctioning procedure and uniformity in the documentation required for loans across all banks, branches and locations.

- Banks should introduce autonomy in the lending process and online tracking can be introduced at the branch level to keep track of the borrowers and their repayment behaviour.

- Banks need to create a credit scoring system for SMEs which automate SME lending and improve credit risk management.

\section{CONCLUSION}

SMEs play a vital role in the progress and development of the Indian economy by contributing significantly to industrial output, exports and employment. It continues to create millions of jobs every year and producing more than 8,000 quality products for the Indian and International markets. Most SMEs are not aware of government-supported assistance schemes. Awareness of government schemes such as MUDRA and CGTMSE is low and inaccessible among SMEs. Banks should simplify their lending criteria and pay attention to opportunities for financing the MSME sector rather than focusing on requirements of high- collateral, charging of high- interest rates and excessive paperwork and cumbersome loan procedure. Banking facilities should be extended to remote areas and staff should be trained to deal with SMEs and they should view themselves as partners in promoting SMEs not just as credit providers. Banks should follow an approach of business based lending not asset-based lending. Banks can provide tailored lending packages to fit the capabilities and financial requirements of SMEs Hence, this study calls for a paradigm shift in banking structure and incentives.

\section{DECLARATION OF CONFLICTING INTERESTS}

The authors declared no potential conflicts of interest with respect to the research, authorship and/or publication of this article.

\section{FUNDING}

The authors received no financial support for the research, authorship and/or publication of this article.

\section{REFERENCES}

Abdulsaleh, M. A., \& Worthington, A. (2016). Bankers perceptions of successful SMEs loan applications: A case study from Libya. The MENA Journal of Business Case Studies, 2016, 117.

Choudhury, M., \& Goswami, C. (2017). MSME Financing Gaps-Research Review 1995-2017. SEDME (Small Enterprises Development, Management \& Extension Journal), 44(3), 1-26.

Chaudhary, S., \& Ahalawat, S. (2014). Credit flow to SMEs in India: A study conducted at Bank of Baroda, International Journal of Commerce, Business and Management, 3(3), 471-474. 
Gupta, V., Saini, J. S., \& Chaddha, S. (2018). Role and Contribution of Commercial Banks in Fulfilling Funding Requirement of MSMEs of Himachal Pradesh" International Journal for Research in Engineering Application \& Management, 4(7).

Ghatule, A., \& Dubey, S. (2016). importance and implication of smes in indian Economy. International Journal of science technology and Management, 5(3), 557-562.

Hall, C., \& Fang, Y. (2004, July). The APEC entrepreneur consortium: active risk management of SME lending through on-line platforms. In Paper to the APEC Conference on Promoting APEC Entrepreneurs: The Financiers Perspective HuaHin Thailand (pp. 29-30).

Irwin, D., \& Scott, J. M. (2010). Barriers faced by SMEs in raising bank finance. International journal of entrepreneurial behavior \& research, 16(3), 245-259.

Jeyaraj, S. S., \& Prakash, A. (2017). Attitude of borrowers regarding the lending services of Bhutan development financial corporation limited. International Journal of Research Science \& Management, 4(11).

Nair, T., \& Das, K. (2019). Financing the micro and small enterprises in India: Antecedents and emerging challenges. Economic and Political Weekly, 54(3), 37-43.

Soumya, K., \& Jayaprada, D. N. (2018). Review of Studies on Micro Small and Medium Enterprises. International Journal for Innovative Research in Science \& Technology, 4(9), 100-106.

Shikumo, D. H., \& Mirie, M. (2016). Determinants lending to Small and medium enterprises by commercial banks in Kenya" IOSR Journal of Economics and Finance, 7(4).

Wangmo, C. (2017). An Exploratory Study On Bank Lending To SME Sector In Bhutan. International Journal of Scientific \& Technology Research, 6(11), 47-51.

\section{APPENDICES}

\begin{tabular}{|l|l|l|l|l|}
\hline SI. No & Years & $\begin{array}{l}\text { Public sector banks } \\
\text { (INR crore) }\end{array}$ & $\begin{array}{l}\text { Private sector banks } \\
\text { (INR crore) }\end{array}$ & $\begin{array}{l}\text { Foreign banks } \\
\text { (INR crore) }\end{array}$ \\
\hline 1 & 2005 & 678 & 86 & 69 \\
\hline 2 & 2006 & 824 & 104 & 84 \\
\hline 3 & 2007 & 1026 & 131 & 116 \\
\hline 4 & 2008 & 1511 & 469 & 155 \\
\hline 5 & 2009 & 1914 & 467 & 181 \\
\hline 6 & 2010 & 2784 & 645 & 211 \\
\hline 7 & 2011 & 3766 & 879 & 215 \\
\hline 8 & 2012 & 3963 & 1105 & 218 \\
\hline 9 & 2013 & 5025 & 1547 & 300 \\
\hline 10 & 2014 & 6160 & 2001 & 300 \\
\hline 11 & 2015 & 8527 & 2815 & 368 \\
\hline 12 & 2016 & 8205 & 3591 & 364 \\
\hline 13 & 2017 & 8289 & 4310 & 365 \\
\hline 14 & 2018 & 8646 & 4108 & 489 \\
\hline 15 & 2019 & 8800 & 5637 & 669 \\
\hline Total & & 70118 & 27895 & 4104 \\
\hline
\end{tabular}




\begin{tabular}{|l|l|l|l|l|}
\hline $\begin{array}{l}\text { Mean } \\
X^{-}\end{array}$ & 4674 & 1860 & 274 \\
& X1 & X2 & X3 \\
\hline
\end{tabular}

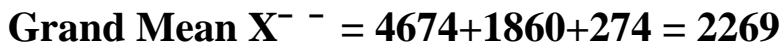

Variance between the samples

\begin{tabular}{|l|l|l|}
\hline$\left(\mathbf{X}^{-} \mathbf{1 - \mathbf { X } ^ { - - }}\right)^{\mathbf{2}}$ & $\left(\mathbf{X}^{-} \mathbf{2 -} \mathbf{X}^{-\boldsymbol{-}^{-}}\right)^{\mathbf{2}}$ & $\left(\mathbf{X}^{-} \mathbf{3 -} \mathbf{X}^{-\boldsymbol{-}}\right)^{\mathbf{2}}$ \\
\hline 5784025 & 167281 & $39,80,025$ \\
\hline 5784025 & 167281 & $39,80,025$ \\
\hline 5784025 & 167281 & $39,80,025$ \\
\hline 5784025 & 167281 & $39,80,025$ \\
\hline 5784025 & 167281 & $39,80,025$ \\
\hline 5784025 & 167281 & $39,80,025$ \\
\hline 5784025 & 167281 & $39,80,025$ \\
\hline 5784025 & 167281 & $39,80,025$ \\
\hline 5784025 & 167281 & $39,80,025$ \\
\hline 5784025 & 167281 & $39,80,025$ \\
\hline 5784025 & 167281 & $39,80,025$ \\
\hline 5784025 & 167281 & $39,80,025$ \\
\hline 5784025 & 167281 & $39,80,025$ \\
\hline 5784025 & 167281 & $39,80,025$ \\
\hline 5784025 & 167281 & $39,80,025$ \\
\hline 5784025 & 167281 & $39,80,025$ \\
\hline 5784025 & 167281 & $39,80,025$ \\
\hline 5784025 & 167281 & $39,80,025$ \\
\hline 5784025 & 167281 & $39,80,025$ \\
\hline 57840250 & 1672810 & $39,80,0250$ \\
\hline
\end{tabular}

Sum of Squares between samples (SSC) 9, 93, 13, 310

\section{Variance within Samples}

\begin{tabular}{|l|l|l|l|l|l|}
\hline $\mathbf{X 1}$ & $\left(\mathbf{X} \mathbf{1 -} \mathbf{X}^{-} \mathbf{1}\right)^{\mathbf{2}}$ & $\mathbf{X 2}$ & $\mathbf{X}^{\left.\mathbf{2}-\mathbf{X}^{-} \mathbf{2}\right)^{\mathbf{2}}}$ & $\mathbf{X 3}$ & $\left(\mathbf{X 3 -}^{\mathbf{-}} \mathbf{3}\right)^{\mathbf{2}}$ \\
\hline 678 & $1,59,68,016$ & 86 & $31,47,076$ & 69 & 42,025 \\
\hline 824 & $1,48,22,500$ & 104 & $13,27,536$ & 84 & 36,100 \\
\hline 1026 & $1,33,07,904$ & 131 & $29,89,441$ & 116 & 24,964 \\
\hline 1511 & $1,00,04,569$ & 469 & $19,34,881$ & 155 & 14,161 \\
\hline 1914 & $76,17,600$ & 467 & $19,40,449$ & 181 & 8,649 \\
\hline 2784 & $35,72,100$ & 645 & $14,76,225$ & 211 & 3,969 \\
\hline 3766 & $8,24,464$ & 879 & $9,62,361$ & 215 & 3,481 \\
\hline 3963 & $5,05,521$ & 1105 & $5,70,025$ & 218 & 3,136 \\
\hline 5025 & $1,23,201$ & 1547 & 97,969 & 300 & 676 \\
\hline 6160 & $22,08,196$ & 2001 & 19881 & 300 & 676 \\
\hline 8527 & $1,48,45,609$ & 2815 & $9,12,025$ & 368 & 8,836 \\
\hline 8205 & $1,24,67,961$ & 3591 & $29,96,361$ & 364 & 8,100 \\
\hline 8289 & $1,30,68,225$ & 4310 & $60,02,500$ & 365 & 8,281 \\
\hline 8646 & $1,57,76,784$ & 4108 & $50,53,504$ & 489 & 46,225 \\
\hline 8800 & $1,70,23,876$ & 5637 & $1,42,65,729$ & 669 & $1,56,025$ \\
\hline
\end{tabular}




\begin{tabular}{|c|c|c|c|}
\hline Total & $\begin{array}{l}\sum_{14,21,36,526}\left(X^{-} 1\right)^{2} \\
14,21,36\end{array}$ & $\sum_{4,36,95,963}\left(X^{2}-X^{-} 2\right)^{2}$ & $\begin{array}{c}\sum\left(X 3-X^{-} 3\right)^{2} \\
3,65,304\end{array}$ \\
\hline
\end{tabular}

Sum of squares within the samples $(\mathrm{SSE})=14,21,36,526+4,36,95,963+3,65,304=18,61,97,793$

\section{Copyrights}

Copyright for this article is retained by the author(s), with first publication rights granted to the journal. This is an open-access article distributed under the terms and conditions of the Creative Commons Attribution license (https://creativecommons.org/licenses/by/4.0). 